University of Nebraska - Lincoln

DigitalCommons@University of Nebraska - Lincoln

Drought Mitigation Center Faculty Publications Drought -- National Drought Mitigation Center

2-20-1978

Extreme Evapotranspiration by Irrigated Alfalfa: A Consequence of the 1976 Midwestern Drought

Norman J. Rosenberg

Shashi B. Verma

Follow this and additional works at: https://digitalcommons.unl.edu/droughtfacpub

Digitairt of the Climate Commons, Environmental Indicators and Impact Assessment Commons,

Epmmpnental Monitoring Commons, Hydrology Commons, Other Earth Sciences Commons, and the

Nettereresource Management Commons

Logo

This Article is brought to you for free and open access by the Drought -- National Drought Mitigation Center at DigitalCommons@University of Nebraska - Lincoln. It has been accepted for inclusion in Drought Mitigation Center Faculty Publications by an authorized administrator of DigitalCommons@University of Nebraska - Lincoln. 


\title{
Extreme Evapotranspiration by Irrigated Alfalfa: A Consequence of the 1976 Midwestern Drought $^{1}$
}

\author{
Norman J. Rosenberg and Shashi B. Verma \\ Agricultural Meteorology Section, Department of Agricultural Engineering, Instilute of Agriculture and \\ Nalural Resources, University of Nebraska, Lincoln 68583 \\ (Manuscript received 24 October 1977, in final form 20 February 1978)
}

\begin{abstract}
The rate of evapotranspiration by irrigated alfalfa at Mead, NE $\left(41^{\circ} 09^{\prime} \mathrm{N} ; 96^{\circ} 30^{\prime} \mathrm{W}\right.$, elevation $\left.354 \mathrm{~m}\right)$ reached record levels in 1976. Evapotranspiration was measured with precision weighing lysimeters in a field 1.9 ha in size. Evapotranspiration ranged during the growing season from 4.75 to $14.22 \mathrm{~mm}^{-1 a y^{-1}}$ and excceded $10 \mathrm{~mm} \mathrm{day}^{-1}$ on one-third of the days studied. On each day of study the ratio of latent heat flux density $(L E)$ to the sum of the net radiation and soil heat flux densities $(R n+S)$ was such that $L E /(R n+S)$ $>1$, indicating the occurrence of significant sensible heat advection. On clear days during mid-summer the net radiation provides energy sufficient for evaporation of no more than $7 \mathrm{~mm} \mathrm{day}^{-1}$. Sensible heat advection provided the remaining energy consumed in evapotranspiration. The unusually strong sensible heat advection likely was due to the generally dry condition of surrounding regions during the drought of 1976.
\end{abstract}

\section{Introduction}

The balance of energy fluxes ${ }^{2}$ over a unit of land surface $[\mathrm{Eq}$. (1)] provides the basis for explanation of the phenomenon we report here:

where

$$
R n+S+L E+A \approx 0,
$$

$$
\begin{array}{ll}
R n & \text { net radiation } \\
S & \text { flux density of heat into or out of the soil } \\
L & \text { latent heat of vaporization of water } \\
E & \text { quantity of water evaporated so that } L E \text { is the } \\
\text { flux density of latent heat from soil and } \\
\text { vegetation to air or from air to soil and } \\
\text { vegetation }
\end{array}
$$

Evapotranspiration (ET) is an energy-consuming process, the energy for which derives originally from solar radiation. In humid regions the energy consumption by $L E$ rarely exceeds the net radiation and is normally less since the air acts as a sink for both latent and sensible heat (Tanner, 1967; van Bavel, 1961). However, in semiarid and arid regions the energy content of the latent heat flux often exceeds that of the net radiation since the crop, if well supplied with water,

I Published as Paper No. 5321, Journal Series, Nebraska Agricultural Experiment Station. The work reported was conducted under Nebraska Agricultural Experiment Station Project 11-049 and Regional Research Project 11-33.

2 Fluxes to the surface are positive and fuxes away from the surface are negative in sign. is a sink for heat. That sensible heat which is consumed is brought to the field by advection from local sources such as adjacent dry fields or from remote sources which are relatively dry. These dry fields or areas become warm with respect to the air passing over and therefore transfer heat to the air (Rosenberg, 1969, 1972).

The advection of sensible heat is of major importance in determining the water balance and the moisture stress imposed on crops grown in large parts of the Soviet Union where the so-called "Sukhovey" winds prevail with varying frequency (Dzerdzeevski, 1957; Lydolph, 1964). Sensible heat advection is a major component of the energy balance in regions of Australia (Stern, 1967; Slatyer and McIlroy, 1961) and in the Great Plains of North America (Rosenberg, 1969, 1972). At our observatory near Mead, Neb., in the east central Great Plains, ET rates by such crops as soybean and alfalfa, when well supplied with water, consistently range on clear days between 8 and $12 \mathrm{~mm}$ (Rosenberg, 1969,1972 ). The net radiant energy accounts for 6-7 $\mathrm{mm}$ of this evapotranspiration. Advection of sensible heat provides the additional energy consumed in the process.

In 1976 lysimetrically measured daily ET rates by irrigated alfalfa in a test field at the University of Nebraska-Lincoln's Agricultural Meteorology Laboratory near Mead $\left(41^{\circ} 09^{\prime} \mathrm{N} ; 96^{\circ} 30^{\prime} \mathrm{W} ; 354 \mathrm{~m}\right.$ MSL) were significantly greater than has been previously reported in the world literature of irrigation science, agronomy and hydrology. Evapotranspiration on three of these days reached record values. Although the worldwide distribution of reliable lysimeters is quite limited, we 


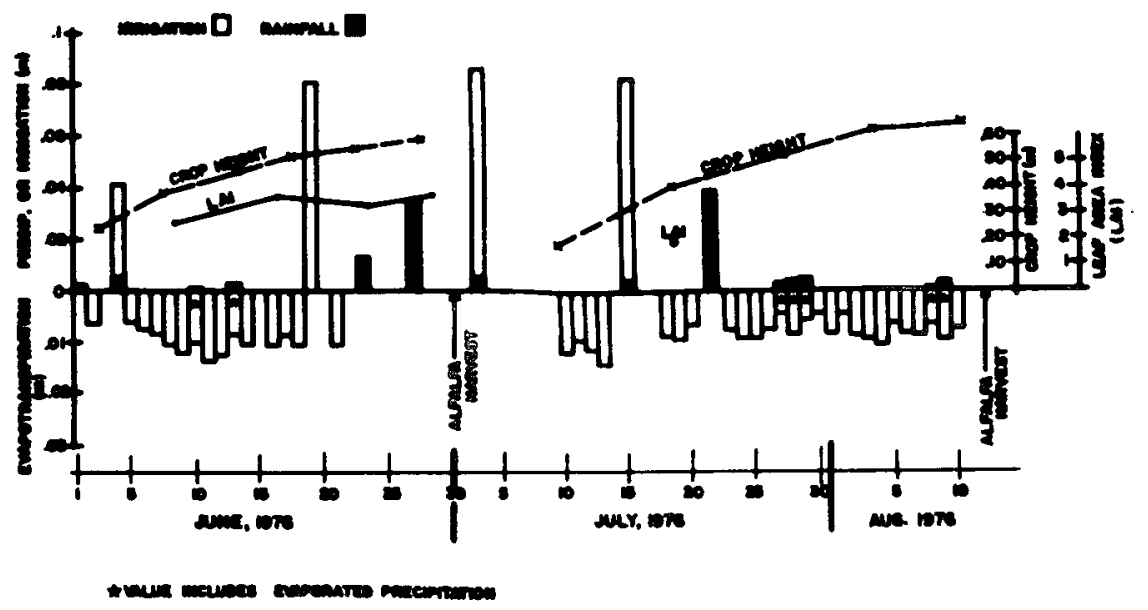

FIG. 1. Rainfall, irrigation and lysimetric evapotranspiration by alfalfa at Mead, NE, 1976. Crop height and leaf area index are also shown.

refer here only to data which were provided by such instruments. Sampling errors inherent in the neutron probe, gravimetric and hydrologic balance methods limit their precision so that short-term estimates of evapotranspiration are not possible. Weighing lysimeters overcome these errors, for the most part.

The severe drought conditions which occurred through much of the midwestern United States in 1976 led to the generation of large quantities of sensible heat. Data presented herein lead us to conclude that regionalscale advection of unusual quantities of sensible heat was the cause of the extreme water consumption.

\section{Methods}

Measurements of evapotranspiration and meteorological conditions reported here were made during summer 1976 in a sprinkler-irrigated field of Sharpsburg silty clay loam, 1.9 ha in size, in which second-year alfalfa (Dawson cultivar) was grown. The field is surrounded, except on the north, by alfalfa of the same age and cultivar. The field is $200 \mathrm{~m}$ long on a north-south line and $95 \mathrm{~m}$ wide.

Precision weighing lysimeters (Rosenberg and Brown, 1970) are located on an east-west line about $120 \mathrm{~m}$ from the southern boundary of the field. The lysimeters are $1 \mathrm{~m}^{2}$ in surface area, contain a soil volume of $1.6 \mathrm{~m}^{2}$ weighing about three tons when wet to approximately the field capacity. A normal soil moisture distribution is maintained by means of forced drainage provided with a manifold of five ceramic candles with bubbling pressure of $\frac{1}{3}$ bar. The soil bins are counterweighted so that the total free movement of the bin results from a weight change of $50 \mathrm{~km}$. Position of the soil bin (and hence its weight) is measured by a strain gauge load cell with a precision of $10 \mathrm{~g}$. Accuracy of the lysimeter has been shown to be $50 \mathrm{~g}$, which is equivalent to a gain or loss of $0.05 \mathrm{~mm}$ of water. Under weather conditions typical of the growing season changes in lysimeter weight are measureable over periods as short as $10 \mathrm{~min}$.

The flux densities of solar radiation, net radiation and soil heat were measured with an Eppley 16 junction pyranometer, ${ }^{3}$ Swissteco Pty. net radiometer, ${ }^{4}$ and a thermal flux plate designed and produced at the Volcani Institute, Israel. Temperature and humidity were measured with self-calibrating thermocouple psychrometers (Rosenberg and Brown, 1974) at a number of locations within the field and with a radiation shielded copper-constantan air thermocouple in combination with a Honeywell dew probe ${ }^{5}$ near the north end of the field. The latter combination of sensors was used to provide data around the clock. The psychrometers were used, primarily, for intensive observations during daytime.

Wind speed was measured at $2 \mathrm{~m}$ above the ground surface with Shepherd-type three-cup anemometers. ${ }^{6}$ Wind direction was determined by means of a wind vane coupled to a variable resistor. All data were recorded with an automated analog-digital data recording system.

The field was irrigated four times in amounts ranging from 42 to $82 \mathrm{~mm}$ during the first half of the experiment (see Fig. 1) in order to provide conditions for potential evapotranspiration. Rain occurred on 16 days during the experiment but in significant amounts on only four days. The first two studies were separated by 10 days to allow for the first cutting of alfalfa on 1 July, irrigation on 3 July, replacement of instruments in the field and partial regrowth of the alfalfa. The crop was cut a second time on 12 August. Plant height was measured periodically during the course of the study. Leaf area

\footnotetext{
${ }^{3}$ Eppley Laboratories, Newport, R.I., model 8-48A.

${ }^{4}$ Swissteco Pty., Melbourne, Australia, type S-1.

5 Honeywell, Minneapolis, Minn., Model SSP 129A.

${ }^{6}$ C. F. Cassela Co., Ltd., London, England, model 442(2).
} 
TABLE 1. Lysimetric evapotranspiration and energy balance of an irrigated alfalfa field and weather conditions.

July-August, 1976 at Mead, NE.

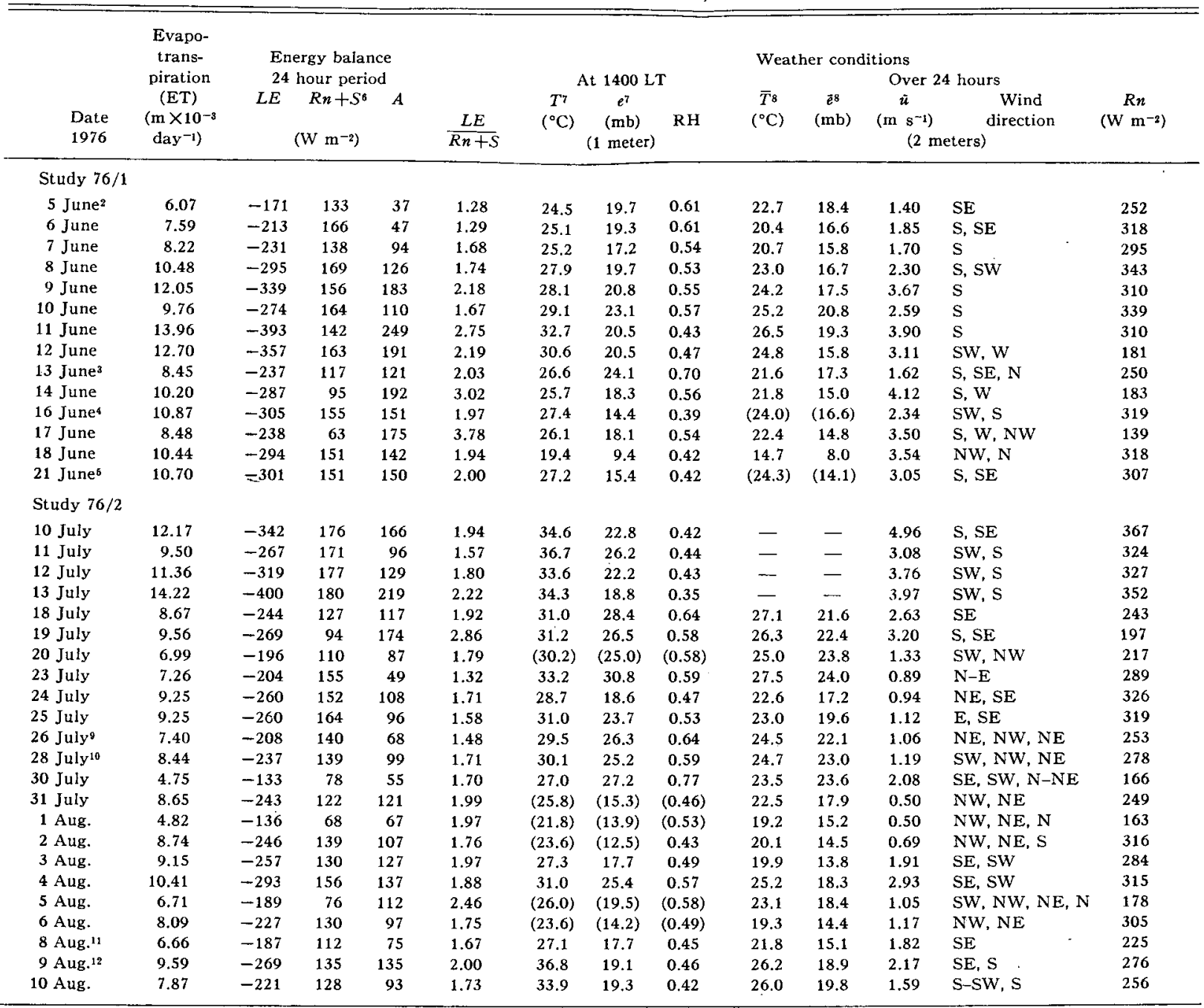

$11 \mathrm{cal} \mathrm{cm}^{-2} \mathrm{~min}^{-1}=697.93 \mathrm{~W} \mathrm{~m}^{-2} ; 1 \mathrm{cal} \mathrm{cm}^{-2} \mathrm{day}^{-1}=0.4846 \mathrm{~W} \mathrm{~m}^{-2}$.

2 Data for $0845-2345$ only.

${ }^{3}$ Rain shower $1415-1430 ; 4.35 \times 10^{-3} \mathrm{~m}$.

4 Lysimeter data begins 0645 .

${ }^{5} T, e, u$ and lysimeter data begins 0715 .

6 $S$ not measured; assumed to be $0.065 R n$ based on calculation of study $76 / 1$.

${ }^{7}$ Psychrometric data except for dew probe and radiation shielded thermocouple where indicated by parentheses.

${ }^{8}$ Dew probe and radiation shielded thermocouple data.

Data ends 2230.

to Rain ended 0630.

11 Precipitation 0400-0430.

12 Precipitation 2200-2230.

index was measured on a number of occasions by means of an electronic area meter. ${ }^{7}$

\section{Results}

Table 1 gives data on the total evapotranspiration and distribution of energy balance components on a daily basis. Solar radiation, temperature, vapor pressure, relative humidity and wind speed and direction

${ }^{7}$ Hyashi-Denko, Japan, model AAM-5. are summarized on a daily basis. Temperature and humidity conditions at 1400 local time (LT) are also given in the table. The ratio $|L E /(R n+S)|$ is given as an indicator of the sensible heat advection. Values greater than unity indicate that sensible heat had been transmitted from air to crop and had been consumed in evapotranspiration.

Lysimetrically measured evapotranspiration ranged from $4.75 \mathrm{~mm}$ on a cloudy, calm day to $14.22 \mathrm{~mm}$ on a windy, clear day. Daily ET exceeded $10 \mathrm{~mm}$ on about 


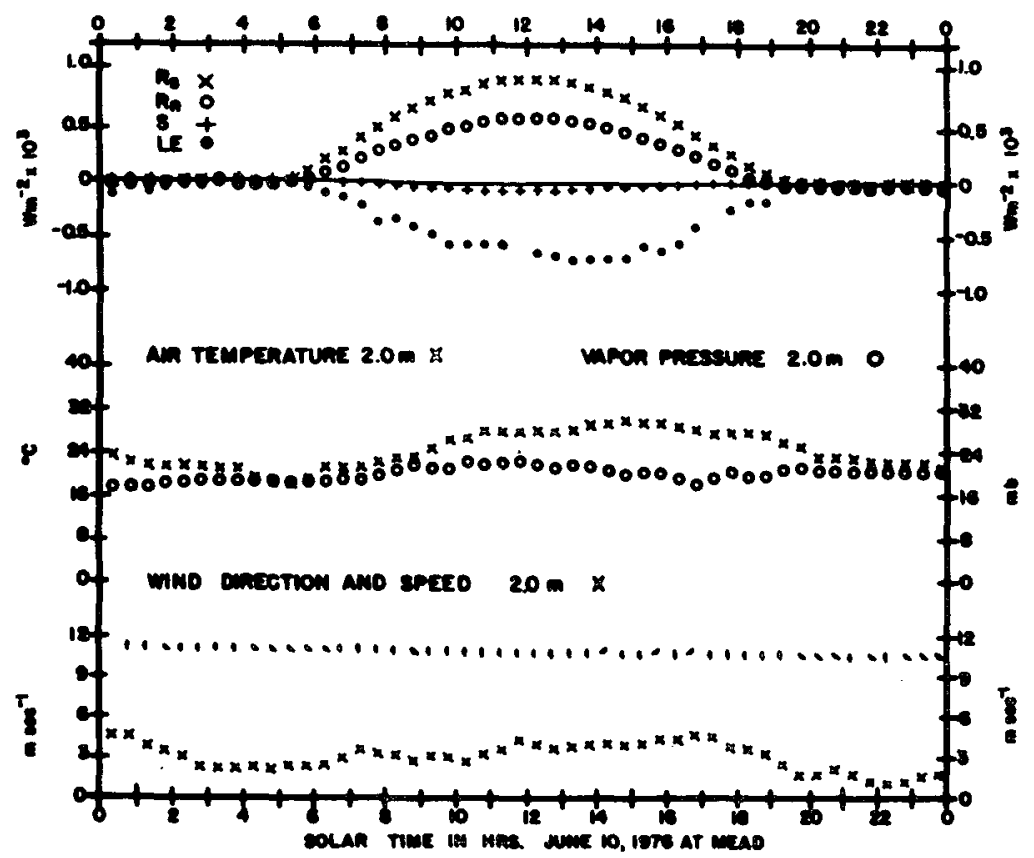

FIG. 2. Energy balance of an irrigated alfalfa crop and weather conditions on 10 June at Mead, NE.

one-third of all days studied. On each day of these studies, including those which were cloudy and calm, the ratio $|L E /(R n+S)|>1$ indicated the occurrence of significant sensible heat advection. ${ }^{8}|L E /(R n+S)|$ ranged from a low of 1.32 on a partly cloudy, relatively humid and calm day to a high of 3.78 on a cloudy, windy and relatively dry day.

The peak values of ET (12-15 $\left.\mathrm{mm} \mathrm{day}^{-1}\right)$ occurred on days which were generally clear and windy with wind direction from southeast through southwest. On these days neither the peak or daily temperatures nor the minimum or daily humidity conditions were unusual or extreme for the season. The patterns of energy partition and ambient conditions on days of typical and extreme water use are shown in Figs. 2 and 3 for 10 and 11 June.

June 10 was a cloud-free day. Winds were from the southeast through south and were relatively consistent during daytime at about $3 \mathrm{~m} \mathrm{~s}^{-1}$. As is typical in the east central Great Plains, evapotranspiration occurred at a low rate during much of the night because of energy transport to the crop from the warmer air above and warmer soil below. $|L E|$ exceeded $(R n+S)$ during the morning hours on 10 June. The rate of latent heat flux was greatest at about 1330 LT. Sensible heat flux augmented the net radiant energy supply and increased the total evapotranspiration by nearly $4 \mathrm{~mm}$.

June 11 began as a cloudy day with moderate winds from the southeast. The sky cleared rapidly after 0930 with the advent of very strong, warm southerly winds.

\footnotetext{
${ }^{8} R n, S$ and $L E$ are measured and the value of $A$ is determined as the residual in Eq. (1).
}

Mean wind speed of about $8.0 \mathrm{~m} \mathrm{~s}^{-1}$ prevailed from 1000-1800 LT. Latent heat flux rates were in excess of $1.5 \mathrm{cal} \mathrm{cm}^{-2} \mathrm{~min}^{-1}\left(\sim 1.5 \mathrm{~mm} \mathrm{~h}^{-1}\right)$ from $1000-1500$. Total evapotranspiration on this day was $13.96 \mathrm{~mm}$.

\section{Discussion}

Regardless of the method by which it has been measured daily ET values $>12 \mathrm{~mm}$ are unusual in the world literature of irrigation science and hydrology. Lysimetric measurements which approach those reported here include $12.20 \mathrm{~mm} \mathrm{day}^{-1}$ for irrigated alfalfa in Phoenix, AZ. (van Bavel, 1967), $11.0 \mathrm{~mm}^{-1 a y^{-1}}$ for irrigated alfalfa at Kimberly, ID. (Wright and Jensen, 1972), $11.56 \mathrm{~mm} \mathrm{day}{ }^{-1}$ for ryegrass at Davis, CA. (Pruitt, 1964), $12.02 \mathrm{~mm} \mathrm{day}^{-1}$ for irrigated alfalfa (Rosenberg, 1969) and soybeans (Rosenberg, 1972) at Mead, NE., and $14.66 \mathrm{~mm} \mathrm{day}{ }^{-1}$ for an isolated $1 \mathrm{~m}^{2}$ stand of sudan grass in a field from which the surrounding crop had been removed (van Bavel et al., 1963). In the latter case the extreme evapotranspiration may have been an experimental artifact caused by the additional solar radiation and advection of locally generated sensible heat from the dry surface penetrating the sides of the isolated stand (Sellers, 1965).

On each day of measurement during the 1976 growing season, daily ET exceeded the input of net radiant energy. Since no similar runs of such long duration have been observed since the Mead Observatory was established in 1966 (reports cited under Rosenberg, Principle Investigator, 1966, 1969, 1972, 1975) we conclude that an unusually intense and constant regime of sensible heat advection prevailed during 1976 . The occurrence of 


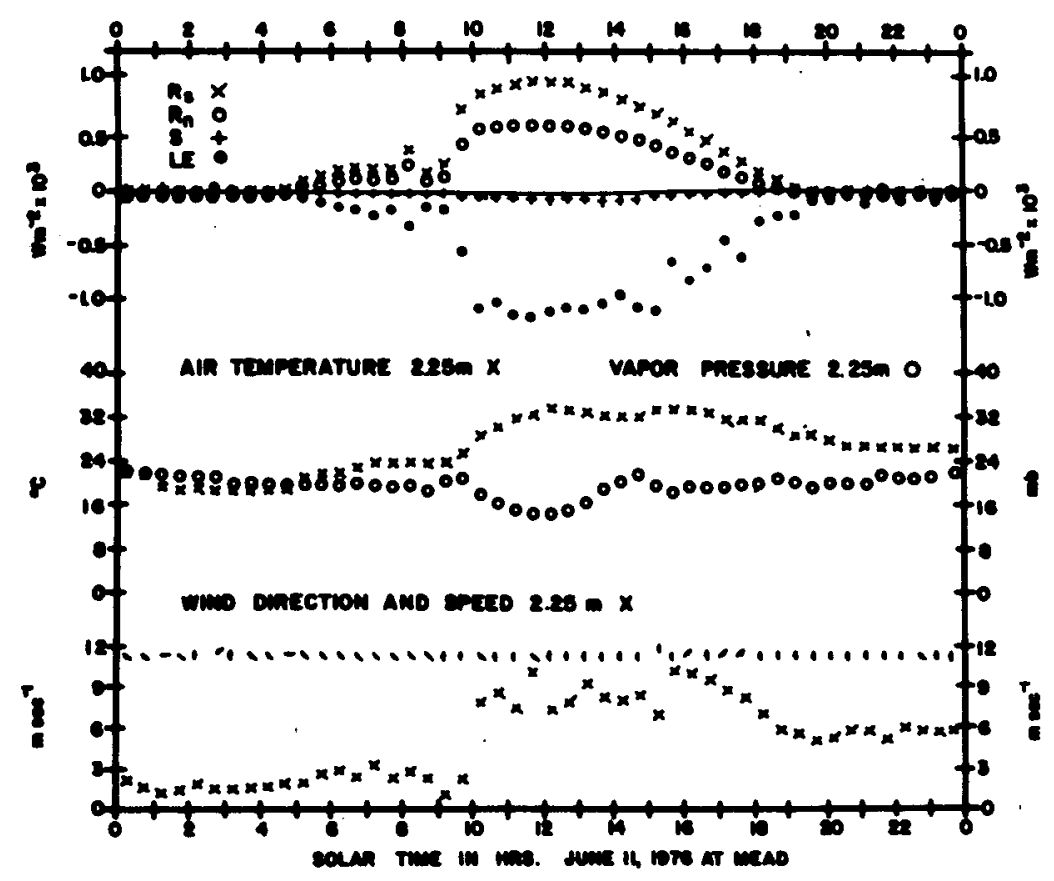

FiG. 3. As in Fig. 2 for 11 June 1976.

daily ET values in excess of $12 \mathrm{~mm}$ and particularly the incidence of days with record values near or greater than $14 \mathrm{~mm}$ indicates that the crops of the region were exposed to unusually severe atmospheric moisture demand during the 1976 season. It is necessary to establish, to the degree of certainty possible, whether or not the data in Fig. 1 and Table 1 do, indeed, indicate a significant departure from "normal". regional climate conditions or whether they represent an experimental artifact following from the choice of crop, the size of field or the use of irrigation.

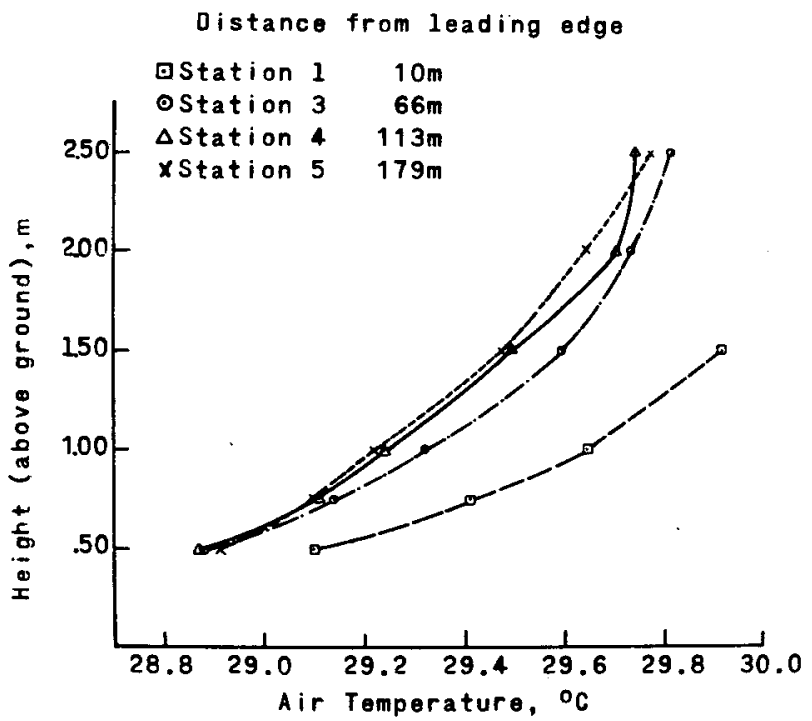

Fig. 4. Profiles of air temperature at varying distances downwind of the leading edge of an irrigated alfalfa field at $1315 \mathrm{LT}$ 10 June 1976 at Mead, NE.
In one Arizona experiment (van Bavel, 1967), alfalfa transpired water for a period of more than 20 days after irrigation at a potential rate determined by ambient climatic conditions. This behavior was explained by the fact that alfalfa exerts a minimal diffusive resistance to the passage of vapor from leaf and canopy into the air above. The deep rooting habit of the crop also contributes to its ability to obtain and transmit water at rates determined by the atmospheric demand. We conclude that alfalfa is an appropriate test crop for our purposes.

All fields in a given region may be subject to the effects of sensible heat advection from dryer regions. An irrigated field in the midst of dry surroundings is subject, additionally, to advection of sensible heat on a local scale. If local effects predominate, the data presented in Fig. 1 and Table 1 may be viewed merely as curiosities. Evidence of strong and continued regional advection, on the other hand, may signify the occurrence of unusually severe and widespread evaporative stress.

In order to investigate the effects of local and regional advection, air temperature profiles were measured at four locations at varying distances downwind from the leading edge of the experimental field (Fig. 4). Temperature differences between the lowest levels at each station were measured differentially with a resolution of $0.0125^{\circ} \mathrm{C}$ using copper-constantan air thermocouples. The same resolution applies to measurements between vertical levels in each of the profiles presented in Fig. 4.

Temperature increasing with height above the crop (inversion conditions) indicates sensible heat transfer from air to crop. Air temperature at Station 1 (10 m 


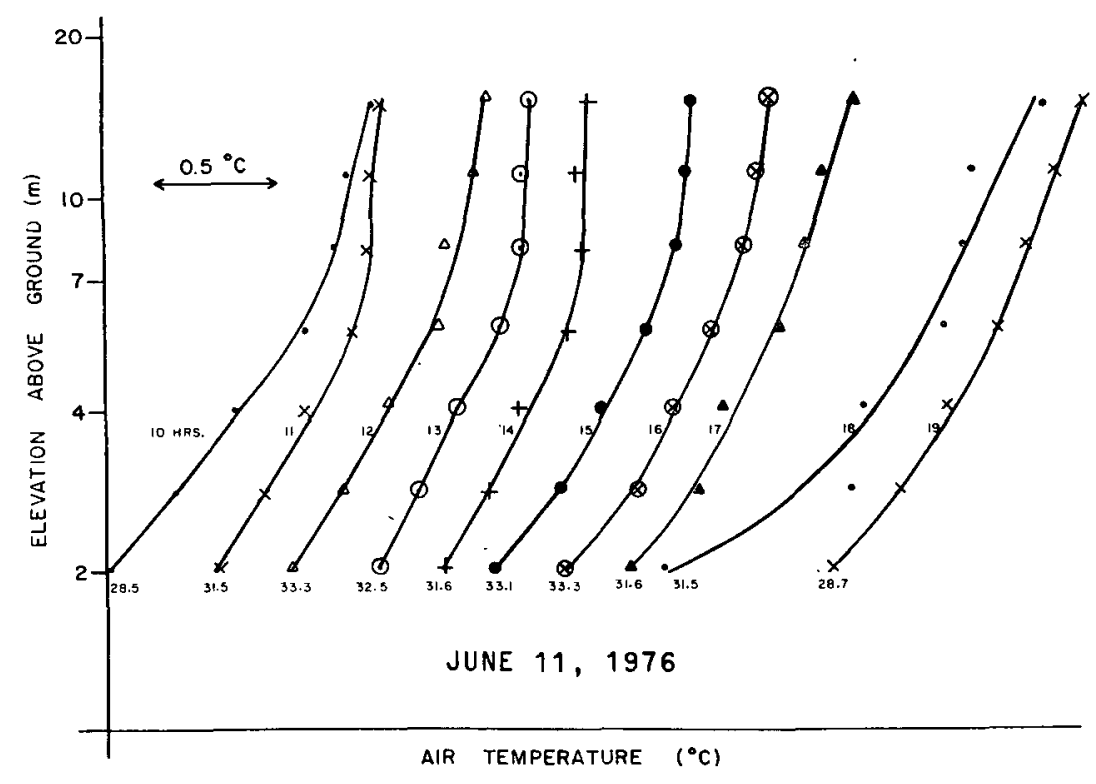

Fig. 5. Progression of air temperature profiles with time of day.

downwind from the leading edge) was $0.2-0.4^{\circ} \mathrm{C}$ greater than at any position further downwind. Temperature equilibration (development of a local boundary layer to the height of the top sensor) was essentially complete at Station 3 (66 $\mathrm{m}$ downwind). The lysimeters were located near Station 4 where the temperature profile had become almost fully equilibrated so that the effects of local advection are fully eliminated before the wind reaches the lysimeters. ${ }^{9}$

Additional evidence that the sensible heat contribution to ET had a significant regional component is given in Fig. 5 where typical air temperature profiles, measured on 11 June with radiation shielded thermocouples (resolution $0.025^{\circ} \mathrm{C}$ ) between 2 and $16 \mathrm{~m}$ on a mast near the north boundary of the field are shown. After $1000 \mathrm{LT}$ air temperature profiles were inverted and remained so throughout the day. Temperature profiles up to $8 \mathrm{~m}$ were always inverted. The inversions occasionally extended still higher. Data presented in Figs. 4 and 5 demonstrate that the experimental field used in these studies was large enough so that the effects of local sensible heat advection are accommodated at its margins. In these circumstances the lysimetrically measured evapotranspiration integrates the contributions of radiant energy and the regional advection of sensible heat.

The extreme evapotranspiration rates measured in eastern Nebraska during the 1976 growing season are shown above to have resulted from unusually strong regional advection of sensible heat. The source of the sensible heat advected into the region is suggested by

\footnotetext{
- Detailed computations of local and regional components of sensible heat advection reported in Brakke (1977) and Brakke et al. (1978) substantiate this conclusion.
}

data in Table 2 where values of the Palmer index (Palmer, 1965) for the growing season (March-October) of the years 1970-76 are shown. In Table 3 the Palmer index is compared on a monthly basis for 1976 for Nebraska and adjoining states.

The Palmer index evaluates the scope, severity and frequency of prolonged periods of abnormally wet or dry weather. The index provides a measure of the overall soil moisture situation for large regions since it considers effective rainfall and potential evapotranspiration (by calculation from current weather conditions). The index is relatively insensitive to the effects of short periods of abnormally wet or dry weather, so that the development of drought or conditions of excessive moisture is indicated rather slowly. Negative values of the Palmer index indicate dryer than normal conditions; positive values indicate wetter than normal conditions.

In the period 1970-75 (Table 2) the growing seasons were generally on the wet, rather than dry, side of normal. A band from Wyoming to Minnesota experienced unusually dry weather in 1974 as did parts of Wyoming and Nebraska during 1975. The growing season of 1976 was, on the average, dryer than normal in all states or areas examined.

Table 3 indicates that during 1976 southwestern Minnesota, South Dakota, eastern Wyoming, and eastern Colorado were dryer than usual by April. All states but Kansas were dryer than normal by June. By the end of the growing season Minnesota and South Dakota, especially, were suffering extreme drought. Two major drought zones extending into Nebraska from the northeast and southwest intensified and became more severe as the season progressed. The most severe of these was centered in northeastern South Dakota. The great geographic extent of the drought 
TABLE 2. Mean Palmer index for the growing season (March-October) for Nebraska and adjoining regions, 1970-76 (see map for districts included).

\begin{tabular}{|c|c|c|c|c|c|c|c|c|}
\hline Kansas & all & 0.4 & 0.1 & 0.5 & 4.7 & 1.7 & 0.9 & -0.3 \\
\hline NW Missouri & 1,3 & 2.3 & -1.2 & -0.6 & 4.7 & 3.3 & 1.6 & -0.5 \\
\hline W Iowa & $1,4,7$ & -0.1 & 0.1 & 1.9 & 4.7 & 0.6 & 0.7 & -0.8 \\
\hline SE Wyoming & 7,8 & 1.1 & 3.7 & 1.1 & 2.3 & -2.1 & -0.9 & -0.3 \\
\hline Nebraska & all & 0.7 & 1.7 & 1.1 & 4.1 & 0.4 & -0.3 & -0.6 \\
\hline
\end{tabular}

Above +4 : extreme wetness.

+3 to +4 : severe wetness.

+2 to +3 : moderate wetness.

-2 to +2 : near normal.

-2 to -3 : moderate drought.

-3 to -4 : severe drought.

Below -4 : extreme drought.

suggests that the sources of sensible heat were unusually large during 1976.

Geographic-climatic analyses, such as the Palmer index, do not provide absolute evidence that the higher than normal evapotranspiration rates experienced at one observatory in eastern Nebraska resulted directly from the intensity of the widespread droughts in the central United States. Drought necessarily results, however, in the generation of greater than normal quantities of sensible heat which are advected within the region of origin and to other regions as well.

The data presented here, aside from their hydrologic and climatic interest, point up the fact that, in times of widespread drought, irrigated lands are exposed to greater than normal evaporative demand. Provision for such periodic increases in demand should be made in the design of irrigation systems and in the planning of water allocations.

\section{Conclusions}

Evapotranspiration rates in a large irrigated alfalfa field in an eastern Great Plains location during 1976 were consistently greater than usual. This resulted from unusually consistent and strong regional scale sensible heat advection. The advection was most likely a result of the drought of 1976 which led to extreme dryness throughout the western, central and northern Great Plains and parts of the adjacent prairie states.

Acknowledgments. We thank our colleagues B. L. Blad and A. Weiss for helpful suggestions. D. E. Sandin and T. Keber assisted in making the field measurements; J. Hines was responsible for data conversion and computation; and R. Sandhorst was responsible for the stenographic production. R. E. Felch and L. Denney of NOAA, EDS provided the Palmer index information. The work reported was accomplished under Grant ATM-10000 A01, Atmospheric Sciences Section, National Science Foundation.

\section{REFERENCES}

Brakke, T. W., 1977 : Local and regional components of sensible heat advection. M.S. thesis, Dept. of Agricultural Engineering, University of Nebraska, 8 pp.

TABLE 3. Monthly distribution of mean Palmer index for Nebraska and adjoining regions during the 1976 growing season (March-October).

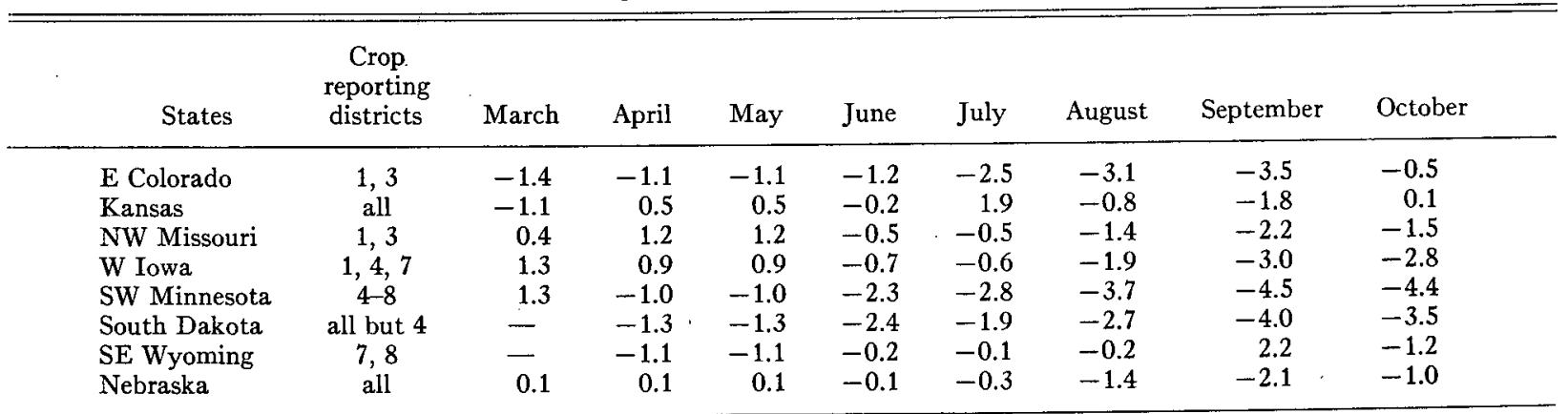


—, S. B. Verma and N. J. Rosenberg, 1978: Local and regional components of sensible heat advection. J. Appl. Meteor. 955-963.

Dzerdzeevski, B. L., Ed., 1957: Sukhovies and drought control. Akad. Nauk. SSSR, Inst. Geogra. [Israel Program for Scientific Translations, Jerusalem, 1963, OTS-63-11140].

Lydolph, P. E., 1964 : The Russian Sukhovey. Ann. Assoc. Amer. Geogr., 54, 291-309.

Palmer, W. C., 1965: Meteorological drought. Weather Bureau Res. Pap. 45, U.S. Dept. of Commerce, 58 pp.

Pruitt, W. O., 1964: Cyclic relations between evapotranspiration and radiation. Trans. Amer. Soc. Agric. Eng., 7, 271-275; 280.

Rosenberg, N. J., Principal Investigator, 1966: Research in evapotranspiration 1966-1967. Report to the Nebraska Water Resources Res. Inst. on Project A-002, Horticult. Prog. Rep. 60.

- 1969: Research in evapotranspiration. Final Report to Office of Water Resources Research on Nebraska Water Resources Res. Inst. Project A-001-NEB, Horticult. Prog. Rep. 73.

- 1972 : Research in Evapotranspiration, 1969-1972. Completion Report to the Office of Water Resources Res. on Nebraska Water Resources Res. Inst. Project A-017-NEB, Horticult. Prog. Rep. 96.

-1977 : Great Plains evapotranspiration by a resistance model using remotely sensed thermal imagery. Project Completion Report to the Office of Water Resources and Technology on Nebraska Water Resources Res. Inst. Project B-028, Agric. Meteor. Prog. Rep. 75-3.

Rosenberg, N. J., 1972: Frequency of potential evapotranspiration rates in the central Great Plains. J. Irrig. Drainage Div. ASCE, 98, 203-206.
- 1969 : Seasonal patterns in evapotranspiration by irrigated alfalfa in the central Great Plains. Agron. J., 61, 879-886.

- , and K. W. Brown, 1970 : Improvements in the van BavelMyers automatic weighing lysimeter. Water Resourc. Res., 6, 1227-1229.

—, and ——, 1974: "Self-checking" psychrometer system for gradient and profile determinations near the ground. Agric. Meteor., 13, 215-226.

Sellers, W. D., 1965: Physical Climatology. The University of Chicago Press, 272 pp.

Slatyer, R. O., and I. C. McIlroy, 1961 : Practical Microclimatology. CSIRO, Australia and UNESCO.

Stern, W. R., 1967 : Seasonal evapotranspiration of irrigated corn in a low-latitude environment. Aust. J. Agric. Res., 18, 259-269.

Tanner, C. B., 1967 : Measurement of evapotranspiration. Irrigation of Agricultural Lands, R. H. Hagan, H. R. Haise and T. W. Edminster, Eds., Agron. Monogr., No. 11, 534-545.

van Bavel, C. H. M., 1961: Lysimetric measurements of evapotranspiration rates in the eastern United States. Soil Sci. Soc. Amer. Proc., 25, 138-141.

- 1967: Changes in canopy resistance to water loss from alfalfa induced by soil water depletion. Agric. Meteor., 4, 165-176.

- L. J. Fritschen and W. E. Reeves, 1963: Transpiration by sudan grass as an externally controlled process. Science, 141, $269-270$.

Wright, J. L., and M. E. Jensen, 1972 : Peak water requirements of crops in southern Idaho. J. Irrig. Drainage Div. ASCE, 98, 193-201. 